\title{
Descriptive analysis of 192 cases of breast cancer occurring before age 40 in Yaounde, Cameroon
}

\author{
Félix Essiben $^{1 *}$, Pascal Foumane ${ }^{1}$, Esther JNU Meka ${ }^{1}$, Michèle Tchakounté2, \\ Julius Sama Dohbit ${ }^{1}$, Christiane Nsahlai ${ }^{1}$, Etienne Atenguena ${ }^{3}$, \\ Philip Nana Njotang ${ }^{1}$, Emile Telesphore Mboudou ${ }^{1}$
}

\begin{abstract}
${ }^{1}$ Department of Obstetrics and Gynecology, Faculty of Medicine and Biomedical Sciences (FMBS), the University of Yaoundé, Cameroon

${ }^{2}$ Department of obstetrics and Gynecology, Higher Institute of Medical Technology, Yaoundé, Cameroon

${ }^{3}$ Department of Oncology, Yaoundé General Hospital, Yaoundé, Cameroon
\end{abstract}

Received: 07 May 2017

Accepted: 03 June 2017

\section{*Correspondence:}

Dr. Félix Essiben,

E-mail: essibenx@yahoo.com

Copyright: ( ) the author(s), publisher and licensee Medip Academy. This is an open-access article distributed under the terms of the Creative Commons Attribution Non-Commercial License, which permits unrestricted non-commercial use, distribution, and reproduction in any medium, provided the original work is properly cited.

\section{ABSTRACT}

Background: Breast cancer is today a global health problem. With 1,671,149 new cases diagnosed in 2012, it is the most common female cancer in the world and accounts for $11.9 \%$ of all cancers and it affects more people than prostate cancer. In 2008, The United States statistics showed that, for all cancer that affect women before 40 years, more than $40 \%$ of them concerned the breast. The aim of this study was to describe the clinical, histopathological and therapeutic aspects of breast cancer in women under 40 years of age in Yaoundé.

Methods: This was a retrospective study with data collected from 192 medical case files of women treated over a period of 12 years, from January 2004 to December 2015 at the Yaounde General Hospital and the Yaounde GynecoObstetric and Pediatric Hospital. Microsoft Epi Info version 3.4.5 and SPSS version 20.0 softwares were used for data analysis.

Results: From 2004 to 2015, 1489 cases of breast cancer were treated in both hospitals. Of these, 462 women were less than 40 years old, representing a proportion of $31.0 \%$. The mean age at diagnosis was $33.5 \pm 5.0$ years and $17.7 \%$ of women had a family history of breast cancer. The average time before an initial consultation was $6.7 \pm 6.6$ months. Most cases were classified as T4 (46.1\%). The most common histological type was ductal carcinoma (87.4\%). Grades SBR II and SBR III were predominant (76.4\%). Axillary dissection (64.4\%) and neoadjuvant chemotherapy (43.9\%) were the main therapeutic modalities. The overall survival rate at 5 years was $51.2 \%$. Five-year survival rates with no local recurrence and no metastatic occurrence were $35.8 \%$ and $43.2 \%$ respectively.

Conclusions: Breast cancer largely affects women under the age of 40 and is often discovered late, at an advanced stage. The prognosis appears poor. Only screening could facilitate diagnosis at an early stage of the disease for better outcomes.

Keywords: Breast cancer, Diagnosis, Outcome, Survival, Young women

\section{INTRODUCTION}

Breast cancer is today a global health problem. With $1,671,149$ new cases diagnosed in 2012 , it is the most common female cancer in the world and accounts for $11.9 \%$ of all cancers and it affects more people than prostate cancer. ${ }^{1}$ In 2008, The United States statistics 
showed that, for all cancer that affect women before 40 years, more than $40 \%$ of them concerned the breast. $^{2}$

Although many authors argue that breast cancer in young women is rare, the proportion of women under 40 years treated for breast cancer is increasing. This proportion often described in the literature, varies between $6.6 \%$ and $31.6 \% .^{2-5}$

These disparate findings could be justified by the quality of the screening modalities. Changes in lifestyles of young women such as an unhealthy quality of life, lack of physical activity, stressful living conditions as suggested by Yeo et al, and most likely the population's greater access to care can explain the increasing incidence of breast cancer by age $40 .^{6}$

In Cameroon, breast cancer accounts for $18.5 \%$ of all cancers in the community. It is the first cancer affecting woman with a frequency of $30 \%$, followed by cervical cancer. ${ }^{7}$ In 2011, Kemfang et al found that about $31.9 \%$ of breast cancers occur before the age of $40 .{ }^{8}$

According to Chollet-Hinton et al, breast cancer in young women is etiologically and biologically different from that in elderly women. ${ }^{9}$ A younger age is likely a pejorative independent prognostic factor of breast cancer because the tumors in young women seem to be more aggressive than those of older women, due to their clinical and histopathological characteristics. ${ }^{5,6,10-12}$ Several other factors may also contribute to this: limited knowledge and awareness of the disease in this age group, diagnosis at advanced stages of disease, limited access to screening facilities and personal and social costs of care.

The clinical management must take into consideration the aesthetic and psychological consequences on the patient, as well as her sexuality and the preservation of fertility. To minimize poor outcomes in patients, these prognostic and contextual factors must be taken into account. Conservative treatment is preferred in young women. Although the therapeutic means needed for acceptable survival are many, they are often limited in the context of resources-scarce country like Cameroon.

The aim of this study was to describe the characteristics of breast cancer in young women in our environment with emphasis on the clinical and histopathological aspects and also the therapeutic approaches to improve the management and survival of these patients.

\section{METHODS}

This was a cross-sectional study with a retrospective data collection on breast cancer in women under 40 years of age who were treated from 1 January 2004 to 31 December 2015 (a 12-year period), at the gynecology unit of the Gyneco-Obstetric and Pediatric Hospital of Yaoundé and the Medical Oncology Department of the
General Hospital of Yaoundé, two reference centers for the management of breast cancer from Central Africa sub-region in general and in Cameroon in particular

After obtaining ethical clearance, the epidemiological, clinical, histopathological and therapeutic parameters were collected from all the patients' files. All these data were entered in a pre-tested data sheet and analyzed using the software Epi info version 3.4.5 and SPSS version 20.0 .

The study performed by 5-year range age groups based on the age of the youngest patient in our cohort. Patients who had never delivered were called nulliparous, those with 1 and 2 children were called pauciparous, those with 3 to 5 children were multiparous, and grand multiparous were those with more than 5 children. The UICC TNM classification was used to stage the disease. The ScarffBloom-Richardson (SBR) grade was used to specify the degree of differentiation of the tumors on pathological examination. The following chemotherapy protocols used were: FAC (5-Fluoro-Uracil, Adriamycin and Cyclophosphamide) and monotherapy with Taxotere. Hormone therapy and target therapies used tamoxifen and trastuzumab respectively.

Quantitative variables were presented as mean and standard deviation. Qualitative variables were expressed as frequency and percentage. Survival was calculated using the Kaplan-Meier survival curve. Survival was assessed by considering the date of origin as the date of the first therapeutic gesture and the end-point as the date of occurrence of the event (death) or the date of the last news. The time of study participation was the time between the initiation of the first therapeutic gesture and the date of the occurrence of the event or date of the last news.

\section{RESULTS}

From 2004 to 2015, 1489 cases of breast cancer were treated in both hospitals. Of these, 462 women were less than 40 years old, this represents a proportion of $31.0 \%$ (462/1489). Out of these only 192 medical case files of cancer patients aged less than 40 years could be analyzed.

\section{Clinical characteristics of patients}

The clinical characteristics of the patients are described in Table 1. The average age of the patients was 33.5 \pm 5.0 years with extremes of 20 and 40 years). Patients aged between 35 and 40 years accounted for $51.6 \%$ (99/192) (Table 1). Most of the patients had given birth at least once in their life $(88.0 \%, 169 / 192)$.

The mean age of onset of menarche was $13.5 \pm 1.6$ years with 10 and 18 years being the lower and upper limits, respectively. Women on oral contraceptives accounted for $15.6 \%(30 / 192)$ of cases. 
Table 1: Clinical data of the patients $(n=192)$.

\begin{tabular}{|c|c|c|c|}
\hline Variables & & $\begin{array}{l}\text { No. of } \\
\text { patients }\end{array}$ & $\begin{array}{l}\text { Frequency } \\
(\%)\end{array}$ \\
\hline \multirow{4}{*}{$\begin{array}{l}\text { consultation } \\
\text { delay (month) }\end{array}$} & $<3$ & 74 & 38.5 \\
\hline & $3-6$ & 48 & 25.0 \\
\hline & $6-12$ & 57 & 29.7 \\
\hline & $>12$ & 13 & 6.8 \\
\hline \multirow{4}{*}{ Age groups } & $20-25$ & 10 & 5.2 \\
\hline & $25-30$ & 29 & 15.1 \\
\hline & $30-35$ & 54 & 28.1 \\
\hline & $35-40$ & 99 & 51.6 \\
\hline \multirow{4}{*}{$\begin{array}{l}\text { Number of } \\
\text { term } \\
\text { deliveries }\end{array}$} & 0 & 18 & 9.4 \\
\hline & $1-2$ & 46 & 24.0 \\
\hline & $3-4$ & 82 & 42.7 \\
\hline & $\geq 5$ & 46 & 24.0 \\
\hline \multirow{3}{*}{$\begin{array}{l}\text { Age at } \\
\text { menarche }\end{array}$} & $<12$ & 49 & 25.5 \\
\hline & $>12$ & 125 & 65.1 \\
\hline & $\begin{array}{l}\text { Not } \\
\text { specified }\end{array}$ & 18 & 9.4 \\
\hline \multirow{2}{*}{$\begin{array}{l}\text { Use of oral } \\
\text { contraceptives }\end{array}$} & yes & 30 & 15.6 \\
\hline & No & 162 & 84.4 \\
\hline \multirow{2}{*}{$\begin{array}{l}\text { History of } \\
\text { breastfeeding }\end{array}$} & yes & 129 & 67.2 \\
\hline & No & 63 & 32.8 \\
\hline \multirow{2}{*}{$\begin{array}{l}\text { Family } \\
\text { history of } \\
\text { breast cancer }\end{array}$} & yes & 34 & 17.7 \\
\hline & No & 158 & 82.3 \\
\hline \multirow{3}{*}{$\begin{array}{l}\text { Topography } \\
\text { of the tumor }\end{array}$} & left breast & 107 & 55.7 \\
\hline & right breast & 80 & 41.7 \\
\hline & $\begin{array}{l}\text { bilateral } \\
\text { disease }\end{array}$ & 5 & 2.6 \\
\hline \multirow{5}{*}{ Tumor size } & $\mathrm{Tx}$ & 10 & 5.2 \\
\hline & $\mathrm{T} 1$ & 7 & 3.6 \\
\hline & $\mathrm{T} 2$ & 37 & 19.3 \\
\hline & $\mathrm{T} 3$ & 49 & 25.5 \\
\hline & $\mathrm{T} 4$ & 89 & 46.4 \\
\hline \multirow{5}{*}{$\begin{array}{l}\text { Presence of } \\
\text { lymph nodes }\end{array}$} & $\mathrm{Nx}$ & 16 & 8.3 \\
\hline & No & 43 & 22.4 \\
\hline & N1 & 92 & 47.9 \\
\hline & $\mathrm{N} 2$ & 31 & 16.1 \\
\hline & N3 & 10 & 5.2 \\
\hline \multirow{3}{*}{ Metastasis } & Mx & 125 & 65.1 \\
\hline & M0 & 41 & 21.4 \\
\hline & M1 & 26 & 13.5 \\
\hline \multirow{4}{*}{ Clinical stage } & Stage I & 2 & 1.0 \\
\hline & Stage II & 46 & 24.0 \\
\hline & Stage III & 127 & 66.1 \\
\hline & Stage IV & 17 & 8.9 \\
\hline
\end{tabular}

The median duration of oral contraceptive use was 2 years with the shortest and longest periods of usage ranging from 3 months to 22 years respectively. The mean age of patients at the first pregnancy was $22.6 \pm 4.9$ years with lower and upper limits of ages 13 and 38 years, respectively. Most of our patients breastfed their babies $(67.2 \%, 129 / 192)$. A family history of breast cancer was found in $17.7 \%$ (34/192) of cases.
Table 2: Pathological data of the patients $(n=192)$.

\begin{tabular}{|c|c|c|c|}
\hline \multicolumn{4}{|l|}{ Variables } \\
\hline \multirow{4}{*}{$\begin{array}{l}\text { Histologic } \\
\text { type }\end{array}$} & $\begin{array}{l}\text { Ductal } \\
\text { carcinoma }\end{array}$ & 170 & 88.5 \\
\hline & $\begin{array}{l}\text { Lobular } \\
\text { carcinoma }\end{array}$ & 12 & 6.3 \\
\hline & Breast sarcoma & 5 & 2.6 \\
\hline & others & 5 & 2.6 \\
\hline \multirow{3}{*}{$\begin{array}{l}\text { Histologic } \\
\text { grade }\end{array}$} & SBR 1 & 22 & 11.4 \\
\hline & SBR 2 & 147 & 76.6 \\
\hline & SBR 3 & 23 & 12 \\
\hline \multirow{2}{*}{$\begin{array}{l}\text { Search of } \\
\text { hormone } \\
\text { receptors }\end{array}$} & yes & 16 & 8.3 \\
\hline & no & 176 & 91.67 \\
\hline \multirow{3}{*}{$\begin{array}{l}\text { Lymph } \\
\text { node } \\
\text { involvement }\end{array}$} & yes & 99 & 51.6 \\
\hline & no & 55 & 28.6 \\
\hline & Not specified & 38 & 19.8 \\
\hline \multirow{2}{*}{$\begin{array}{l}\text { Search for } \\
\text { CA 15-3 } \\
\text { level }\end{array}$} & yes & 44 & 22.9 \\
\hline & no & 148 & 77.1 \\
\hline \multirow{2}{*}{$\begin{array}{l}\text { Search for } \\
\text { Ki67 }\end{array}$} & yes & 12 & 6.3 \\
\hline & no & 180 & 93.7 \\
\hline
\end{tabular}

The average delay time for initial consultation was $6.7 \pm 6.6$ months (range between 7 days and 3 years). The time between the appearance of the first symptoms and the date of the first consultation was less than or equal to 3 months in $38.5 \%(74 / 192)$ of patients. The presence of a breast nodule was the most common reason for consultation $(81.8 \%, 157 / 192)$.

The left breast was most affected $(55.7 \%, 107 / 192)$. The upper-outer quadrant was the most frequent location $(73.4 \%, 141 / 192)$. The mean breast nodule size at admission was $6.9 \pm 3.8 \mathrm{~cm}$ (range between 1 and $20 \mathrm{~cm}$ ) and $55.7 \%(88 / 158)$ of the patients had a nodule of more than $5 \mathrm{~cm}$ diameter. Lymph nodes were involved in $57.8 \%(111 / 192)$ of cases.

We found that most patients were diagnosed at a locally advanced stage (T4 and T3) of the disease that is $71.8 \%$ $(138 / 192)$ and axillary lymph nodes were positive in $47.9 \%(92 / 192)$ of patients. Distant metastases were found in $13.5 \%(26 / 192)$ of cases at the time of diagnosis.

\section{Histopathological characteristics of tumors}

Pathological data are reported in Table 2. Ductal carcinoma was the most common histological type with $87.5 \%(168 / 192)$ of cases and the histological SBR grade was high (2 and 3 ) in $88.5 \%(170 / 192)$ of patients. Lymph node was affected in $68.8 \%(99 / 144)$ of cases. Hormone receptors were searched for in $8.3 \%$ (16/192) of patients and were present in $62.5 \%(10 / 16)$ of them.

The level of CA15-3 was not often sought (22.9\%, $44 / 192)$, but was high in $43.2 \%(19 / 44)$ of cases. The 
Ki67 receptor was searched in $6.3 \%(12 / 192)$ of the patients and was present in $75.0 \%(9 / 12)$ of cases.

\section{Therapeutic aspects}

The treatment modalities are shown in Figure 1. Chemotherapy was the first-line therapy in $43.8 \%$ $(84 / 192)$ of patients, however overall $84.9 \%$ (163/192) of patients received chemotherapy.

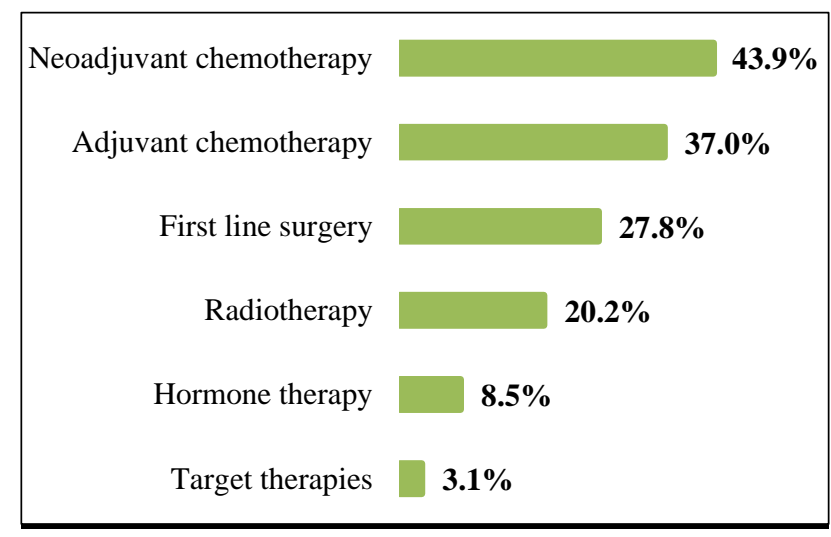

Figure 1: Distribution of patients based on type of treatment $(n=192)$.

Surgery, when performed $(75.0 \%, 144 / 192)$, was most often radical mastectomy with axillary lymphadenectomy $(81.9 \%, 118 / 144)$.

After an average follow-up of 8.1 months, $27.6 \%$ $(53 / 192)$ of patients experienced a relapse of the disease, as assessed by locoregional recurrence $(19.3 \%, 37 / 192)$, distant metastasis $(17.2 \%, 33 / 192)$ or contralateral breast cancer $(13.5 \%, 5 / 37)$. The most frequent metastatic recurrence site was in the lungs $(69.7 \%, 23 / 33)$.

The overall 5-year survival rate was $51.2 \%$ (Figure 2). The non-event 5-year survival rate was $35.8 \%$ (Figure 3 ).

The five-year survival rate without loco-regional recurrence was $39.3 \%$ (Figure 4 ). The 5-year survival rate without metastatic recurrence was $43.2 \%$ (Figure 5).

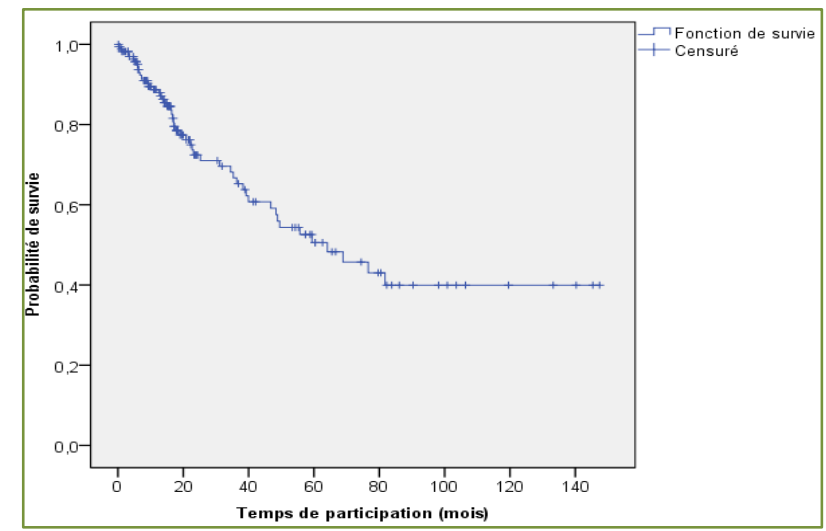

Figure 2: Overall survival curve.
The mean time to locoregional recurrence was $60.7 \pm 6.2$ months with upper and lower limits of 48 and 73 months, respectively, whereas the mean time to relapse metastasis was $69.0 \pm 6.5$ months with extremes of 56 and 81 months.

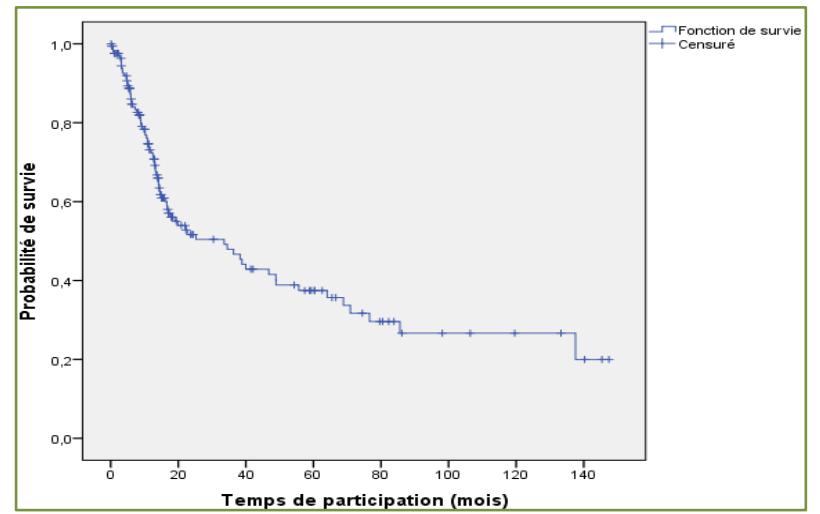

Figure 3: Event-free survival curve.

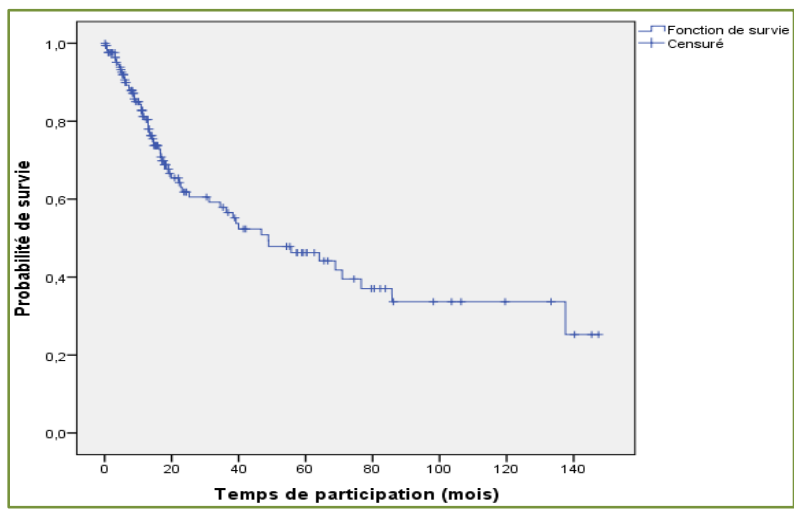

Figure 4: Survival curve without metastatic relapse.

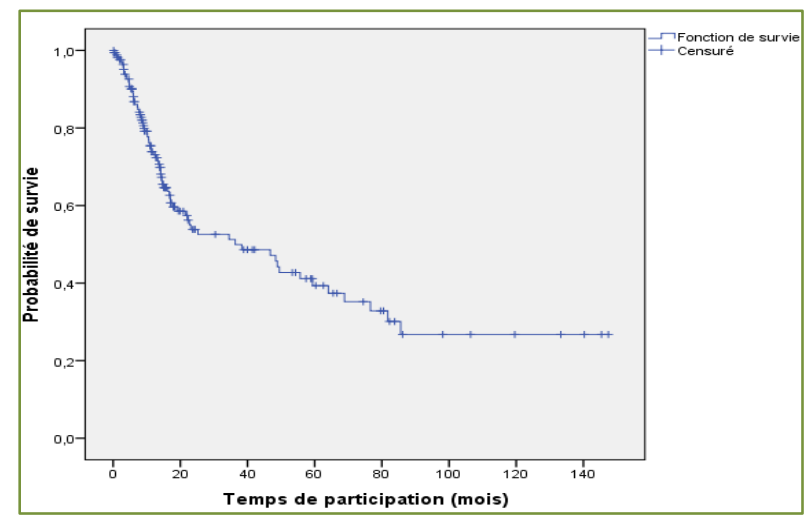

Figure 5: Survival curve without loco regional relapse.

\section{DISCUSSION}

The proportion of women under the age of 40 years with breast cancer in our study is comparable to that previously reported by Kemfang et al in Cameroon. ${ }^{8}$ This rate is higher than those described elsewhere., ${ }^{2,3}$ In a study done in Cameroon, Essiben et al found that women with breast cancer were often under the age of 50 years. ${ }^{13}$ 
The short life expectancy of women in Cameroon means that women die before they develop breast cancer, which may explain the high proportion of young women in the population of women with breast cancer.

The role of parity and breastfeeding in the occurrence of breast cancers is controversial in the literature. In 2016, Chollet-Hinton et al showed that parity is associated with a higher risk of breast cancer in young women in the United States9. High parity would increase the risk of normal cell transformation to tumor cells during tissue maturation that occurs during each pregnancy. ${ }^{14}$ However, other authors have accused nulliparity, attributing this to the inducers of the cellular multiplication, estradiol and the prolactin, whose levels are higher in the nulliparous women. ${ }^{6,15,16}$ There were few nulliparous women in our study. Essiben et al showed that, nulliparity was a protective factor in Cameroon. ${ }^{17}$

In our study, most women had breastfed. The protective role of breast-feeding, also referred to by Chollet-Hinton et al in the United States, was questioned by Merviel et al, in France for whom the risk of cancer is increased by nulliparity and absence of breastfeeding. ${ }^{9,15}$ These two factors have contradictory effects in our results.

The search for a genetic background in a breast cancer is indicated when the woman is young. The presence of breast cancer in the family history significantly increases the risk. ${ }^{18}$ Genetic factors are also incriminated when the woman is very young. A significant proportion of women in our cohort $(17.7 \%)$ had a family history of breast cancer, which is close to the studies already published. ${ }^{19}$ Genetic mutations are not often tested in our environment, because either patients do not have enough financial resources, or the limited technical expertise in running these tests.

Breast cancer before the age of 40 has its peculiarities. Its diagnosis can be influenced by factors described in the literature. ${ }^{2,6,9,15}$ About half of the women in our cohort were under 35 years of age. The sensitivity of diagnostic tests is lower in young women. The density of mammary tissue decreases the sensitivity of self-examination and mammography. ${ }^{20,21}$ The low index of suspicion of cancer in younger patient often leads to misdiagnosis at early stage.

Young women's breast cancer is often diagnosed at an advanced stage. ${ }^{11,22-24}$ An abnormally long duration prior to consultation helps explain this finding. It was more than 6 months in our study with the vast majority of cancers diagnosed at a locally advanced or metastatic stage. This is consistent with studies previously done in Cameroon and elsewhere. ${ }^{5,8}$ This delay in consultation could be attributed to the rapid progression of the disease among young women who, although they themselves discovered their cancers, did not seek medical help for various reasons. ${ }^{24,25}$
Regardless of their ages, the population's selfexamination of the breasts and immediate consultation in case of anomaly favor early diagnosis and therefore an appropriate management. The histological features that make breast cancer of the young woman more aggressive are not sought in our environment. However, this may help to improve management and consequently establish disease prognosis. The onerous nature of diagnostic facilities limits access to these technologies. The search for hormone receptors was carried out only in a very small number of patients. This limited the eligibility for endocrine adjuvant therapies such as targeted therapy or hormone therapy. Other studies have found similar findings. ${ }^{26,27}$

Chemotherapy was often first-line therapy due to the advanced stage of the disease. Chemotherapy is more beneficial for young women because it significantly reduces the risk of local recurrence and mortality. ${ }^{28}$ Young women tend to prefer conservative treatment. ${ }^{29,30}$ It is the preferred therapeutic choice because radical treatment is mutilating and deleterious for women's psychology. Unfortunately, radical mastectomy was most often performed in present study. This is justified by the limited financial resources of the patients, the advanced stage of the disease at the time of diagnosis and the limited means of investigation and treatment. Moreover, access to chemotherapy and radiotherapy is often limited even if patients are able to pay for.

Limited access to adjuvant therapies due to financial constraints may explain the high rates of recurrence observed in our cohort. There is no health insurance system to help in the cost of treatment. More than onethird of the patients had recurrence in the year of treatment. Overall survival was poor. Other authors have reported better results. ${ }^{5,19}$

The study results are due to inadequate diagnostic and management services. Pathologic diagnosis is insufficient. Innovative techniques for determining the characteristics of tumors for better management are not accessible.

\section{Limitations}

Limitations of this study were the sample size, compounded by incomplete information contained in the medical records as well as absence of a significant part of the records of patients treated for breast cancer in both services.

\section{CONCLUSION}

The proportion of women under the age of 40 suffering from breast cancer is high. A family history of breast cancer seems to play an important role. Late diagnosis affects therapeutic outcome. 
The education of women of all ages in self-screening, improved access to histological and prognostic diagnostic tools and greater accessibility to all therapeutic modalities could improve survival of breast cancer in women under the age of 40 in Cameroon.

\section{ACKNOWLEDGMENTS}

Authors would like to thank Dr Tongo Passo Aimé marcel for its contribution to the study. The authors wish also to acknowledge the authorities of the Yaoundé Gynaeco-obstetric and Paediatric Hospital (YGOPH) and the Yaoundé General Hospital (YGH) who allowed to carry out the study in their institutions.

Funding: No funding sources Conflict of interest: None declared

Ethical approval: The study was approved by the Institutional Ethics Committee of YGOPH

\section{REFERENCES}

1. International Agency for Research on Cancer Globocan 2012: estimated cancer incidence, mortality and prevalence worldwide in 2012/populations fact sheets. 2012. Available at http://globocan.iarc.fr/pages/fact_sheets_population. aspx.

2. Anders CK, Johnson R, Litton J, Phillips M, Bleyer A. Breast Cancer Before Age 40 Years. Semin Oncol. 2009;36(3):237-49. WB Saunders

3. Kheirelseid EAH, Boggs JME, Curran C, Glynn RW, Dooley C, Sweeney KJ, et al. Younger age as a prognostic indicator in breast cancer: A cohort study. BMC Cancer. 2011;11:383.

4. Thangjam S, Laishram RS, Debnath K. Breast carcinoma in young females below the age of 40 years: A histopathological perspective. South Asian J Cancer. 2014;3:97-100.

5. Slaoui M, Mouh FZ, Ghanname I, Razine R, El Mzibri M, Amrani M. Outcome of breast cancer in moroccan young women correlated to clinicpathological features, risk factors and treatment: a comparative study of 716 cases in a single institution. PLoS ONE 11 (10): e0164841.

6. Yeo W, Lee HM, Chan A, Chan EY, Chan MC, Chan KW et al. Risk factors and natural history of breast cancer in younger Chinese women. World J Clin Oncol. 2014;5(5):1097-106.

7. Enow Orock GE, Ndom P, Doh AS. Current cancer incidence and trends in Yaounde, Cameroon. Oncol. Gastroenterol Hepatol Rep. 2012;1(1):58-63.

8. Kemfang NJD, Yomi J, Kasia JM, Mawamba Y, Ekortarh AC, Vlastos G. Breast cancer profile in a group of patients followed up at the radiation therapy unit of the Yaounde General Hospital, Cameroon. Obstet Gynecol Int. 2011;2011:143506.

9. Chollet-Hinton L, Anders CK, Tse CK, Bell MB, Yang YC, Carey LA, et al. Breast cancer biologic and etiologic heterogeneity by young age and menopausal status in the Carolina Breast Cancer study: a case-control study. Breast Cancer Res. 2016;18(1):79.

10. Lee MK, Varzi LA, Chung DU, Cao M, Gornbein J, Apple SK, et al. The effect of young age in hormone receptor positive breast cancer. Biomed Res Int. 2015;2015:325715.

11. Bano R, Salim M, Abid M, Akif Zaidi, Khan AI. Prognosis of breast cancer in very young age (less than 30 years). J Cancer Allied Spec. 2016;2(1):4.

12. Mazeh H, Sagiv I, Katz D, Freund HR, Peretz T, Allweis TM. Association between patient age, volume of breast tissue excised, and local recurrence. The J Surg Res. 2013,181(2):187-192.

13. Essiben F, Foumane P, Mboudou E, Dohbit J, Mve Koh V, Ndom P. Diagnosis and Treatment of Breast Cancer in Cameroon: A Series of 65 Cases. Mali Medical. 2013;28:1-5.

14. Butt S, Borgquist S, Garne JP, Landberg G, Tengrup I, Olsson A et al. Parity in relation to survival following breast cancer. Eur J Surg Oncol. 2009;35(7):702-8.

15. Merviel P, Jouvance O, Naepels P, Fauvet R, Cabrygoubet $\mathrm{R}$, Gagneur $\mathrm{O}$, et al. Are there still risk factors for the onset of breast cancer? Gynecol Obstet Fertil. 2010;39́(2011):486-90.

16. Parsa P, Parsa B. Effects of reproductive factors on risk of breast cancer. Asian Pac J Cancer Prev. 2009; 10:545-50.

17. Essiben F, Foumane P, Meka ENU, Soh PS, Dohbit JD, Osogo E, et al. Risk factors for breast cancer: a case-control study of 315 women followed in the Gynecology and Oncology Departments of Two University Teaching Hospitals in Yaounde, Cameroon. Open J Obstet Gynecol. 2016;6:676-88. Available http://dx.doi.org/10.4236/ojog.2016.612085.

18. Ravdin PM, Cronin KA, Howlader N, Berg CD, Chlebowski RT, Feuer EJ, et al. The decrease in breast-cancer incidence in 2003 in the United States. N Engl J Med. 2007;356(16):1670-4.

19. Bakkali H, Marchal C, Lesur- Schwander A, Verhaeghe JL. Breast cancer in women aged 30 and under. Cancer Radiother. 2003;7:153-9.

20. Boufettal H, Noun M, Samouh N. Breast cancer in young women in Morocco. Cancer Radiother. 2010;14:698-703.

21. Checka CM, Chun JE, Schnabel FR, Lee J, Toth H. The relationship of mammographic density and age: implications for breast cancer screening. AJR Am J Roentgenol. 2012;198(3):292-5.

22. Xiong Q, Valero V, Kau V, Kau SW, Taylor S, Smith TL, et al. Female patients with breast carcinoma age 30 years and younger have a poor prognosis: the M.D. Anderson Cancer Center experience. Cancer. 2001;92(10):2523-8.

23. Harirchi I, Kolahdoozan S, Karbakhsh M, Chegini N, Mohseni SM, Montazeri A, et al. Twenty years of breast cancer in Iran: downstaging without a formal screening program. Ann Oncol. 2011;22(1):93-7. 
24. Burgess CC, Ramirez AJ, Richards MA, Love SB. Who and what influences delayed presentation in breast cancer? Br J Cancer. 1998;77(8):1343-8.

25. Fancher TT, Palesty JA, Paszkowiak JJ, Kiran RP, Malkan AD, Dudrick SJ. Can breast self-examination continue to be touted justifiably as an optional practice? Int J Surg Oncol. 2011;965464.

26. Murphy CC, Bartholomew LK, Carpentier MY, Bluethmann SM, Vernon SW. Adherence to adjuvant hormonal therapy among breast cancer survivors in clinical practice: a systematic review. Breast Cancer Res Treat. 2012;134: 459-78.

27. Johnson RH, Hu P, Fan C, Anders CK. Gene expression in young adult type breast cancer: a retrospective analysis. Oncotarget. 2015;6:13688702. PMID: 25999348.

28. Reyna C, Lee MC. Breast cancer in young women: special considerations in multidisciplinary care. J. Multidiscip Healthc. 2014;7:419-29.
29. Morrow M, White J, Moughan J, Owen J, Pajack T, Sylyester J, et al. Factors predicting the use of breastconserving therapy in stage I and II breast carcinoma. J Clin Oncol. 2001;19:2254-62. PMID: 11304779.

30. Menard S, Casalini P, Cascinelli N, Balsari A. Breast carcinoma in young patients. Lancet. 2000;356:1113.

Cite this article as: Essiben F, Foumane P, Meka EJNU, Tchakounté M, Dohbit SJ, Nsahlai C, Atenguena E, Njotang PN, Mboudou ET. Descriptive analysis of 192 cases of breast cancer occurring before age 40 in Yaounde, Cameroon. Int J Reprod Contracept Obstet Gynecol 2017;6:2704-10. 